\title{
Urbanism Prehispanic in The Andes
}

\author{
Ing.arch. Fernando Valdez \\ Skolitel: Doc.Ing.arch.Karel Havliš \\ Vedoucí ústavu FA VUT Brno
}

For a long time experts of the subject's origin and evolution of urban life and urban planning, especially Europeans, believed that in pre-Hispanic America there was no real urban life and urban planning itself until after the European conquest. The pre-Hispanic urbanism is one of the most contentious issues in South America, with differing positions regarding the concept, a chronology of the process, the role of supposedly sophisticated city, and the characteristics of social and economic context. The discussion necessarily focuses on the area of the Central Andes (Peru and Bolivia) since the northern part of the subcontinent, including Ecuador between the end of the Formative Period and the Inca conquest, maintained close relations with development in Central America and Mexico, on the other hand, beyond the limits of the Inca Empire none of the prehistoric societies of the American Continent had established systems of urban settlement, there was not any other culture who deserve the adjective urban.

\section{Objective.}

The aim of this project is: to show that culture in Andean America had its own process in the field of urban planning, it had an evolution from formative period untill maximum expression in the Inca Empire, they created their own and perfect cities, subsequently suffered a break and were replaced with urban models and concepts brought of the old world.

\section{The essence of urbanism in The Andes.}

After developing several regional cultures began to establish and consolidate in a single dominant city, the Wari Empire was the forerunner of the Great Inca Empire. The Wari culture (700 AD to $1200 \mathrm{AD}$ ) was developed almost in parallel with the culture of Tiwanaku (300-1100 AD), both cultures were the basis of the great Inca Empire further developed. Its expansion was mainly religious, as the god Wiracocha was known in the Andean world, facilitating the expansion of Wari through it.

The Wari Empire among its many features has made urban planning in the Andean world, becoming one of the earliest civilizations to develop the design of cities reaching a level of perfection. But the concept of the city had already been introduced by the Nazca (culture that preceded the Wari [200-600 AD] and gave rise to the city neighbourhoodsand housing).

The need to build cities for the Wari was that they represented the power and were centers of administration, rather than places where the population was concentrated. From these places were irradiated religious imposition and dissemination of the Wari culture in the conquered areas. The idea spread by the researchers is that of an urban model Wari could be repeated in various parts without the need to be built by the builders themselves, without thereby not change its size, importance or complexity. The researchers also note that the origins of urbanism Wari would be more than the Central Andes of Tiahuanaco, as much as the architecture itself has been influenced by the Altiplano.

The Wari have developed the phenomenon of urban design, and not just the proliferation of cities is the high degree of planning which built their cities, including 
with schools for this purpose, where architects learned and then performed spatial and principles structural architecture. First rose the walls of the contour, and within the space was subdivided into grids to make the most, and in some cases to build the channels before the rest of the city, which is a testament to hight evolution of their urban planning

\section{The urbanplanning in Wari Culture.}

The city of Wari in its most important development was the capital itself, which was the cultural, economic, religious seat of power, civil and military. Although today we find semi destroyed and buried, we found it occupied an area of 2,000 hectares, large city for its time, where planned water distribution and divided the city into districts or sectors, each with its specific function, so we have: Cheqowasi, Monqachayuq, Capillayuq, Vegachayuq, Moqo, Moraduchayuq, etc. The city housed at least 50000 people and meet basic functions of economic, social, political, religious and cultural.

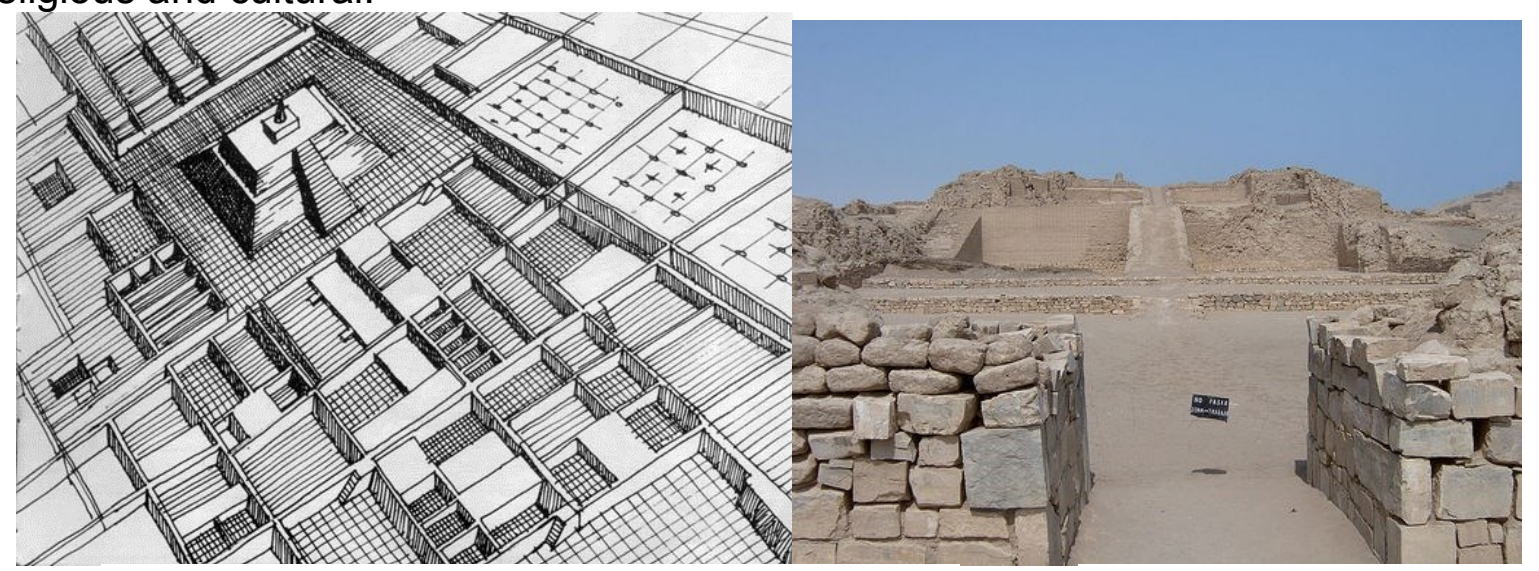

Fig 1. Scheme Wari's City. temple.

Fig 2. Ruins Wari's City, view of

The pattern of urban settlement type Wari was orthogonal (Fig. 1), consisting of sets of large enclosures that held rigid rectangular building housing complexes organized around a central courtyard. The walled enclosures usually had only one entrance and no domestic buildings, because apparently for security reasons was entered themclimbing over the walls.

The urban layout was organized by the existence of narrow streets that were intercepted and orthogonally linked to large urban complexes that constitute the neighborhoods of the city. Naturally, there were also places, open spaces, ceremonial platforms and buildings for worship and public administration (Fig. 2).

The Wari city because of its spontaneous origin, provided the capital and explosive and continuing growth, did not conform to rigid standards of urban Wari, but instead the planned provincial cities accomplished the state urban settlement patterns.

Although the trend was Wari urban secularization, through state planning, then when they abandon the old ceremonial centers and new towns are built on the model, and Wari designed from a detailed development plan and seems to indicate some type centers Cuzco Viracochapampa, Typee, Incaraqay. Urban center are 
served by an extensive road network, involving the base of the posterior and effective communications network for the Incas.

\section{The urban planning of the Inca Empire.}

Centuries later released a new culture emerged from an Andean group, which in mid-thirteenth century occupied a part of the Cuzco Basin and from the fifteenth century achieved a state organization. However spread everywhere, today is a major pre-Columbian civilization of the Andes.

The great Inca Empire reached its greatest territorial expansion from the Pacific coast to the Amazon River valley. They established the capital in the city of Cuzco, the most important pre-Columbian metropolis on the American continent, who considered the center of the universe (capital of the empire and meaning "navel of the world"). The rule, which they called Inca Empire - which means "the four parts of the world - was divided into four regions. In turn, these were divided into provinces. In front of the Inca empire was conquered areas were addressed by the governor and local chiefs. The Inca Empire was formed at the same time as the Aztec, XIV century, and lasted until the Spanish conquistadors arrived in 1530.

Many features of the Inca Empire, as its state constitution, the rectilinear urban planning and its communication system were inherited from earlier cultures. However, the Incas absorbed all knowledge could improve and create new cities, giving it its own style, the best example Cuzco (Fig. 3).

The history, tradition and reality indicate that the Inca city was shaped like a Puma, a cat that was seen as the special deity among the Quechua. As evidence of this, the name of Pumakurko Street remains, and represents the "backbone of the Puma"; Pumaqchupan district or "Puma's Tail" is at the juncture of Saphi ( "Root") and Tullumayu ( "Rio Bone "or" River Delgado "). In addition, the head is located in Saqsaywaman that his name derives from "the SAQS uma" or "marbled head". According to tradition Cusco was the shape of a cougar squatting.

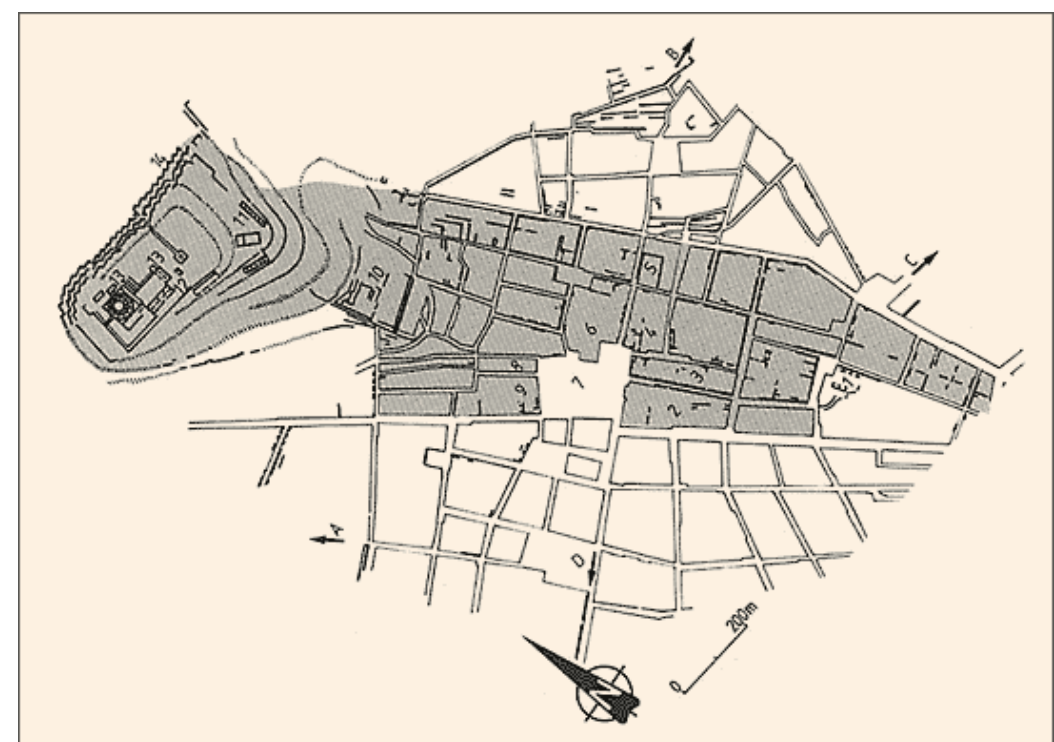

Fig.3 The city of Cuzco figure resembles a cougar sleeping. 
The ancient Incan metropolis was divided into two groups and divided into 13 large districts organized according to classical planning, characterized by a large open space in the city center "Plaza". The most important buildings were around the great square, were mainly palaces of some of the Inca Rulers of the Company. Among them was the palace of the Inca Pachakuteq. To the north was the palace of Inca Roqa Qoraqora appointed. The palace of the Inca Wiraqocha the Kiswar Kancha. In front of the palace was a Suntur Wasi, a building which had a cylindrical shape and served as the home of the arms and emblems. The Hatun Kancha which belonged to Inka Yupanqui located east of the former. The Amaru Kancha was the palace of Wayna Qhapaq. Front of that palace there was another Suntur Wasi. In the area of downtown were some other palaces as was Pukamarka Inka Tupac Yupanqui palace still see the magnificent walls Maruri Street. Also Hatunrumiyoq Palace and the Palace of Qollqanpata located in the current church of St. Cristobal.

Each palace occupied a wide territory, usually an entire block, and must have housed the Inca Panaka, whole his family (ancestors, descendants and some other relatives). Around Kusipata there was no other palace, but the areas were already prepared and walled for future buildings. In short, it was a city organized and enjoyable.

But the Inca Empire, due to its large expansion also left small towns built outside of Cuzco, small towns to the Inca emperors, among them are: "Ollantaytambo" and in the heart of the Andes, and impresses us today: "Machu Picchu" the most important urban design, this citadel was built between 1460 and 1470 , was used as a royal residence and place of religious retreat. Although it was discovered barely a century ago, the citadel of Machu Picchu and the Inca Empire reveals reached a sophisticated urban design in the field. Most buildings are part of the town and served as a residence, but there are also shops, temples and other public buildings.

Although Machu Picchu is not due to any previous design, we assumed that was built in accordance with their natural environment, with its constructions following natural curves and ups and downs of the earth. But some experts say that urban design of the citadel and surrounding space, contain elements that are part of the Andean world (mountains and big rocks, caves and springs), reinforce the idea that it was a sanctuary. All buildings at Machu Picchu are the classic Inca architectural style and she has been able to track many of the details of Inca urban planning. 


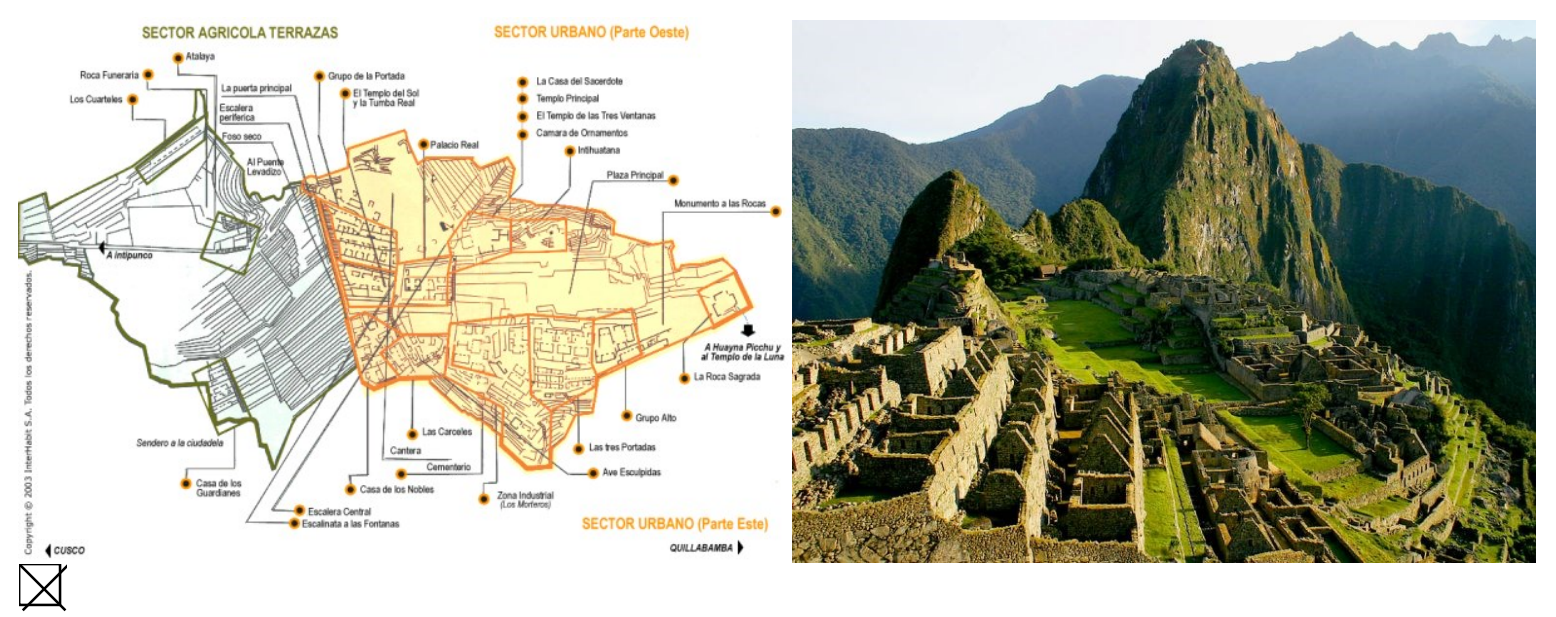

Fig.4 Map and view of Machu Picchu

Machu Picchu basically consists of two sectors: agricultural and urban areas (Fig. 4). The agricultural area consists of terraces of crops. The urban area consists of streets, stairways, water canals, squares and other minor constructions. The buildings are basically rectangular and a floor. The windows are trapezoidal doorways and niches where they placed the idols or other objects. Since there are no ceilings due to the passage of time, it is estimated that were built with logs and covered with straw.

\section{Between Past and Present of urbanism in The Andes}

The trend towards urbanization of society is clearly seen Andean America since the formative period, the planning was a mechanism of expansion and control of religious ideas, political and economic. Until the time Inca, The city was an administrative center that since its power, controlled the resources. Andean American urbanism sometimes perform the role of test instrument of conquest and power, was always a practical urbanism, who understood the constraints of adapting to it rather than using resources rationally in the environment.

The Wari planning can proceed in the Central Andes and tendency to remain, which affords a high urban planning, with regional characteristics, producing variations in the models.

With the subsequent arrival of the settlement was interrupted and just a great American culture in the Andes, within the urban area may show that there are cities that have currently take the concepts and models of pre-Hispanic cities, there are some concepts maintained: as the large central open space that was before the Inca palaces and religious shrines, but these have been merged into new urban concepts brought from the old world, the concept of large open space emerged from the combination of past experiences, both European as Americans, faced with the reality of conquest. The large open space or now called "The Plaza" was the result of the combination of European traditions, colonial Spaniards and pre contextualized within the process of conquest and colonization of Latin America. e. $g$ (the main square in Cuzco and Plaza de Armas in Lima, Peru). 
With colonization and the implantation of urban concepts to new cities in Andean America, it began a new era in America were essentially orthogonal concepts with the famous checkerboard which was imposed on cities and was the main feature in the cities Andean America. The European conquest was a drastic change to the pre-Hispanic models, with conflicting results and different.

\section{Bibliografy}

G. Bawden, Domestic Space and Social Structure in Pre-Columbian Northern Peru, in S. Kent (ed.), Domestic Architecture and the Use of Space: An Interdisciplinary Cross-Cultural Study, Cambridge 1990, pp.153-171.

E. Bonnier - H. Bischif, Arqueológica Peruana 2: Arquitectura y civilización en los Andes Prehispánicos, Mannheim 1997.

A. von Hagen - C. Morris, The cities of the Ancient Andes, London 1998.

"Huari Empire." About (2002)

http://archaeology.about.com/od/archaeologistsw/g/wari.htm

"Empires across the Andes." National Geographic Magazine (2002) http://magma.nationalgeographic.com/ngm/0206/feature5/ 